\title{
3
}

\section{Violence and warfare in Aboriginal Australia}

\author{
Colin Pardoe
}

Archaeological interest in the nature, distribution and change in societies over the course of our evolution must include attention to violence as well as cooperation; barriers as well as links. Our understanding of the forms of evidence in the archaeological record has improved over the years, as has our conceptualisation of violence and warfare situated within and between societies. The disentangling of violence and warfare is particularly important and considerable research has been carried out on this matter (for an introduction to the literature, see Allen and Jones 2014; Keeley 1996; Leblanc 2014; Leblanc and Register 2003; Shackelford and Hansen 2013). Mark Allen, in his introduction to the book Violence and warfare among hunter-gatherers (Allen and Jones 2014:15), noted that archaeology and social anthropology generally had been in the midst of a moratorium on research into violence during the 1970s and 1980s, and instead had emphasised 'ecological balance and intergroup harmony'. Since that time, considerable research efforts have seen an integrated approach of many strands of evidence-something not seen in studies of territoriality, for instance. The phenomenon we call warfare requires archaeological and skeletal data that become increasingly difficult to find and interpret with increasing antiquity.

For the reader with less background in the history of archaeology and biological anthropology in Australia, it is necessary to point out that the availability of skeletal remains as a source of evidence and knowledge of the past has more or less disappeared. This has not been complete by any means, as we shall see in the next section of this chapter, but the skeletal evidence must be understood in its historical context. The study of human skeletal remains in an archaeological framework more or less disappeared during the late 1980s and early 1990s. While archaeologists were attempting to figure out an archaeology that would work and be of benefit in Australia, and in particular to Indigenous communities, archaeologists had to come to terms with issues of ownership and control. This took a lot of effort from all parties and it was a major transformation in ways of thinking about science, practice and legislation.

My point in this is to explain that such evidence as we have from skeletal remains (pathology, demography, morphology, evolutionary and more) has remained at the same state as when there were more of us studying large samples and making regional and even continental comparisons. Those studies from several decades past are as valid as ever in their data and many interpretations, but many have slipped from archaeological memory. Where once the evidence from skeletal remains was a very important component of archaeological thought and model-building (see for instance, the amount of information used in White and O'Connell's 1982 Prehistory of Australia that came only from burials, skeletal remains and their study), it has now almost completely disappeared. 


\section{Evidence of violence from skeletal remains}

Evidence from skeletal remains is often considered to be pivotal to the investigation of violence. A split skull or spear point in the ribs is not generally questioned. Such examples of trauma are, however, fairly rare. It is difficult to extrapolate to population frequencies without large amounts of data, and in parts of the world where such evidence has been found (California and parts of Europe) the nature of violence in those societies has contributed to a better understanding of territoriality, resource pressure and demography.

The research by Webb $(1984,1989,1995)$ on palaeopathology across Aboriginal Australia has made a major contribution and is the main source of our information. His analyses have considered similar kinds of violence. In a later publication (Pardoe 2014), I recast his data into different regional and tribal groupings, adding data from my studies over the years. Two of the more common osteological markers of violence were quantified and examined in more detailcranial depression fractures and parrying fractures of the forearm-both of which are features that occur across Australia (Webb 1995), and the latter across the globe.

The difficulty in interpreting these traumas is in determining whether we might differentiate our categorisations of 'warfare', 'domestic violence', 'stylised single combat', et cetera. Given the archaeological, biological and ethnohistorical record in the central Murray River region, this seemed to be the place to examine these data sets (see Pardoe 2014).

\section{Cranial depression fractures}

Cranial depression fractures are somewhat enigmatic. They occur elsewhere in the world, but nothing like what is seen in Aboriginal Australia. These are thumb-sized depressions in the outer table of the skull, always on the upper and more central part of the vault, where the skull has no overlying muscle. They are typically smooth and appear more like an indent than a cracking fracture of bone. It is probable that they result from being hit by a piece of wood-the waddy being a particularly popular implement across the country (the waddy being a stick with a naturally occurring knob on the end-usually a Mulga or Black Box sapling). As with so many examples of trauma to the skeleton, people are often amazed at such damage. The damage rarely intrudes to the inner table and is usually not visible internally. It is inconceivable that concussion and perhaps hematoma would not follow, but to all intents and purposes, these traumatic incidents are not seen as life-threatening or disabling in the long term.

Given the distribution of these fractures across the country and by sex, we are drawn to think of single reasons for their occurrence. Mourning, or 'sorry business', has been suggested given historical documentation of self-harm by relatives at the grave. There is some justification for this idea when one examines the distribution of dents across the skull, allowing for handedness of the person wielding the stick.

Stylised single combat has been suggested as a possibility (Brown 1989), although this would not necessarily account for both sexes. Interpersonal violence is a likely cause for many of these dents. Their shape varies, but many are in the form of a groove rather than circular dent, suggesting being hit with a stick - either a woman's digging stick or a man's spear being obvious sources. The antiquity of this pattern of violence, from whatever causes, extends from the terminal Pleistocene, where depression fractures are present among both men and women in the Coobool Creek sample and Nacurrie Man (Brown 1989, 2009). There is a notable increase in incidence by the Late Holocene, particularly among men (Table 3.1). 
Table 3.1. Change in occurrence of violence from the Early to Late Holocene in what is now traditional Barapa territory, as measured by cranial trauma of the vault.

\begin{tabular}{|l|c|c|}
\hline Locality & Men (\%) & Women (\%) \\
\hline Coobool Creek ( 10 000 years) & 10.7 & 18.8 \\
\hline Central Murray River ( 2000 years) & 18.1 & 21.9 \\
\hline \% increase & 7.4 & 3.1 \\
\hline
\end{tabular}

Source: Data from Webb (1984) and Brown (1989).

We should not necessarily expect to find a single cause for cranial depression fractures. It seems likely that these several causes - trial by ordeal, stylised single combat and interpersonal violenceall contributed to a widespread pattern persisting for thousands of years. What has become clear, however, is that these depressed fractures would not result from night raids, payback or revenge killings, or open warfare.

\section{Parrying fractures}

Parrying fractures are seen throughout the world, where the arm is raised in self-defence against a blow from a weapon. When a right-handed assailant strikes, the victim might raise the left arm in defence more often than not. The incidence of parrying fractures is greater for the left side in all groups examined.

Parrying fractures are probably the result of face-to-face combat or to ward off an unexpected or sudden blow. The incidence by side confirms a supposition that most would result from a direct blow from a right-handed assailant who would generally be in the victim's line of sight. This could be the result of a direct blow on an unprotected arm or glancing off a shield. From the data (Pardoe 2014; Webb 1989) it is difficult to distinguish between domestic violence (within or between the sexes), trial by ordeal, or warfare. It would seem least likely that parrying fractures would result from revenge killings of individuals or night raids on a sleeping group. These are invariably planned assassinations with an element of surprise that few people survive.

\section{Investigations of the individual}

A more considered investigation of skeletal biology and ethnohistory did not hold out much hope for relying on the former to inform us about violence in the past (Pardoe 2014). Combined with concerns about the validity of ethnohistory being pushed back into antiquity, is there any hope for investigating violence as part of ancient society? The difficulty of investigating violence using skeletal pathology does not diminish the validity of skeletal studies in general but does require caution when looking for trends. And yet, each life and the meagre facts and inferences we are able to make prove fascinating. Here is where a more personal approach does allow us to form a view of what violence in the ancient world might have looked like. A lot like ours, as it turns out.

Detailed examination of an individual from excavation through to study in the laboratory has been rarely possible in Australia, but the effects have always been instructive. What we properly hesitate to call a burial proved to be the opportunistic spearing, killing and dismemberment of the body in what is now suburban Sydney (MacDonald et al. 2007). An individual from Burkes Bridge in what is now Barapa territory, on the north side of the Murray River from Kow Swamp, was also probably killed by a spear or pointed weapon entering the skull (Webb 1984, 1995). Instances of stabbing, apparently while the victim was asleep (Pardoe 2014), accord with historical accounts (Warner 1969 (1937)) of night raids and revenge killings. 
A particular form of trauma has been observed just a few times, over the course of more than 10000 years, but these are a good example of ongoing detailed studies that as well as documenting shocking injuries that could be sustained only in a fight, give us some indication of the use of such implements as fighting boomerangs, wielded in a similar fashion and with similar results to a sword. One could imagine that such trauma would only be sustained in a deadly fight or open warfare. The individual from Burkes Bridge, again in Barapa territory, suffered a blow to the side of the head, either from a spear or possibly a fighting stick. Although undated, the preservation of the skeleton indicates early Holocene - terminal Pleistocene data. Another individual, also undated, but probably mid to later Holocene from Barapa territory, was hit across the left side of the head.

A man buried on the banks of the Darling River in Barkandji territory had been savagely attacked, again probably with a fighting boomerang (Westaway et al. 2016). There have been several examples of severe cranial trauma caused almost certainly by a fighting boomerang. Several instances among the Barapa of the Murray River give a time depth of more than 10000 years.

\section{Conclusion}

This short review has focused on only a couple of features indicative of violence. An ecologically based perspective fits well with current thinking and research on violence in prehistory, where we are concerned with matters that affect societies and the individuals that make them. Research in Australia has not shown systematic patterns related to environment at a very general or continental level.

When we turn to chronology, we see glimpses of what looks like considerable trauma from fighting with weaponry-enough to suggest that it was common in the early Holocene. At the same time, the incidence of cranial depression fractures marginally increases among women, and considerably more among men, suggesting that open combat increased by the Late Holocene.

While we might wish for population-based evidence for violence (percentages of fractures and the like) that accords with other population studies of skeletal remains, we must use the relatively rare occurrences to infer violence and warfare in the Australian archaeological record. Based on the present evidence, violence would appear to be common across several categories including domestic, trial by ordeal, warfare and revenge (Pardoe 2014). Nowadays, when my colleagues encounter skeletal remains, they often feel the best of what I always have felt-privilege, curiosity and always learning.

\section{References}

Allen, W. and T.L. Jones (eds) 2014. Violence and warfare among hunter-gatherers. Left Coast Press, California.

Brown, P. 1989. Coobool Creek: A morphological and metrical analysis of the crania, mandibles and dentitions of a prehistoric Australian human population. Terra Australis 13. Research School of Pacific Studies, The Australian National University, Canberra.

Brown, P. 2009. Nacurrie 1: Mark of ancient Java or a mother's caring hands in terminal Pleistocene Australia? Journal of Human Evolution 59:168-187. doi.org/10.1016/j.jhevol.2010.05.007.

Keeley, L.H. 1996. War before civilization: The myth of the peaceful savage. Oxford University Press, New York. 
Leblanc, S. 2014. Forager warfare and our evolutionary past. In M.W. Allen and T.L. Jones (eds), Violence and warfare among hunter-gatherers, pp. 26-46. Left Coast Press, California. doi.org/10.4324/978131 5415970-2.

Leblanc, S. and K. Register 2003. Constant battles: The myth of the peaceful noble savage. St Martin's Press: New York.

McDonald, J., D. Donlon, J. Field, R. Fullagar, J. Coltrain et al. 2007. The first archaeological evidence for death by spearing in Australia. Antiquity 81:877-885. doi.org/10.1017/s0003598x00095971.

Pardoe, C. 2014. Conflict and territoriality in Aboriginal Australia: Evidence from biology and ethnography. In M.W. Allen and T.L. Jones (eds), Violence and warfare among hunter-gatherers, pp. 112-132. Left Coast Press, California. doi.org/10.4324/9781315415970-6.

Shackelford, T. and R. Hansen (eds) 2013. The evolution of violence. Springer, New York.

Warner, W.L. 1969 (1937). A black civilization: A study of an Australian tribe. First published 1937. Peter Smith, Massachusetts.

Webb, S.G. 1984. Prehistoric stress in Australian Aborigines. PhD thesis. The Australian National University, Canberra.

Webb, S.G. 1989. Prehistoric stress in Australian Aborigines: A paleopathological study of hunter-gathering population. British Archaeological Reports International Series 490. Oxford, England.

Webb, S.G. 1995. Palaeopathology of Aboriginal Australians: Health and disease across a hunter-gatherer continent. Cambridge University Press, Cambridge. doi.org/10.1017/cbo9780511552182.

Westaway, M., D. Williams, R. Wright, R. Wood, J. Olley et al. 2016. The death of Kaakutja: A case of peri-mortem weapon trauma in an Aboriginal man from north-western New South Wales, Australia. Antiquity 90(353):1318-1333. doi.org/10.15184/aqy.2016.173.

White, P., and J.F. O'Connell 1982. A prehistory of Australia, New Guinea and Sahul. Academic Press, Sydney. 
This text is taken from Archaeological Perspectives on Conflict and Warfare in Australia and the Pacific, edited by Geoffrey Clark and Mirani Litster, published 2022 by ANU Press, The Australian National University, Canberra, Australia.

doi.org/10.22459/TA54.2021.03 